日臨外医会誌 $53(6), 1241-1248,1992$

棕説

骨盤内藏器全摘術の適応と限界

\author{
山口大学第 2 外科 \\ 内山哲史鈴木 木 敌 \\ 千葉大学第 2 外科 \\ 碚 野 可一
}

1.はじめに

骨盤内腔には, 消化器系, 泌尿器系, 生殖器系の捗 器及び骨盤を形成する骨が近接して存在するといら解 剖学的特性がある。このためそれぞれの䁍器に発生し た覀性腫場は進行すると容易に周团藏器に漫潤し，こ れらの悪性腫崵を㮛治的に切除しようとすると周囲藏 器を含めた広範な切除術, 即ち骨盤内脿器全摘術が要 求される。

骨盤内葴器全摘術は, 1948年 Brunschwig'に上り局 所的に進行した 1 例の S 状結腸癌之21例の骕人科的

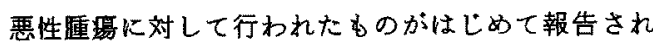
た。, 又, 1950年 Appleby ${ }^{21}$ は長期予後を含めた本術式の 意義を報告した。しかしながら、これらの報告におけ る尿路变更術は wet colostomyであったため尿路系 の合併症が多いことが問題であった．Bricker ${ }^{3 / 4)}$ は回 腸導管による尿路变更術を導入してこの問題点を解決 しこここに骨盤内䠞器全摘術の基本術式が確立された。 本邦では，1951年に高安ら5により第 1 例が報告され t.

骨盤内絾器全摘術は，骨盤内腫焬に対する最も根治 的な術式であり，最近のストーマ管理もを含む術前術 後管理の進歩と，手術死亡率が $4.3 \%^{7)}$ 之低く安全な手 術であることから頻繁に行われるようになっている。

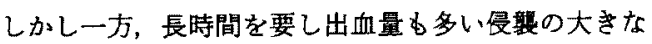
手術であり，更に術後は double stoma となり患者の quality of life (QOL) に対して大きな負担を与える。 このため手術の施行にあたっては本術式の適応と限界 をしっかり見極めることが重要である。

本論文では，はじめに骨盤内䁍器全摘術の一般的適 応を述へ，後に適応決定上の問題点㧍よびそれらの対 策について述へた，更に，新しい㧓式として非便，排 尿機能を温存した骨盤内茼器全摘術の可能性について も言及した。

2. 適応となる疾患

骨盤内喴器の悪性缠瘍で隣接葴器浸潤例が対象とな
る. 消化器系では直腸癌, S 状結腸癌などの下部大腸 癌, 肛門癌, 泌尿器系では耪胱, 前立腺, 尿道などの

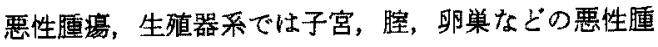
漡があり，これらの悪性隀瘍の初発例，再発例が主な 適志となる899. 表 1 亿当科で施行された32例の内訳 を，表 2 にそれそれの浸潤藏器を示す. Bricker ${ }^{10)}$ の218 例の報告ではこの他に放射線照射による骨盤内葴器の 壊死症例に対しても骨盤内臓器全摘術を施行してい 万。

女性では，子宮，胵が骨盤内の中央に位置するため， 面晹癌，膀胱癌は先ずこれらに漫潤し，この時期であ

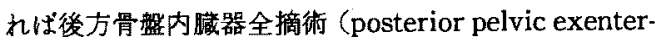
ation）または前方骨盤内䁍器全摘術（anterior pelvic

\section{表 1 骨看内䑏器全摘術症例}

\begin{tabular}{|c|c|}
\hline 直腸癌 & 12例 \\
\hline S 状結腸癌 & 3例 \\
\hline 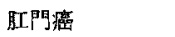 & 1例 \\
\hline 骨盤腄瘦 & I例 \\
\hline 直儤癌再発 & 2例 \\
\hline S状結渴癌再発 & 2例 \\
\hline 子宮路 & 1例 \\
\hline 子宫平滑飤肉嗹 & 1例 \\
\hline 子宮源再発 & 9例 \\
\hline 柿 & 32 例 \\
\hline
\end{tabular}

表 2 漫潤跬器

\begin{tabular}{|c|c|c|}
\hline & $\mathrm{S}$ 状結腹癌さたは直腸癌 & 子宫癌 \\
\hline 䲞脱 & 12例 & 6 例 \\
\hline 直䭪 & 2例 & 6 例 \\
\hline 子宮 & 1例 & \\
\hline 䧑 & 4例 & I例 \\
\hline 前士立腺 & 2例 & \\
\hline 尿管 & 1例 & \\
\hline 仙骨 & 3 例 & 1 例 \\
\hline
\end{tabular}

(山口大学第 2 外科) 
exenteration)が適応となるが，更に進行した症例，ま たは子宮筋腫などで子宮摘出の既往を有する症例では 男性と同様に本論文で述べる骨盤内澸器全摘術（total pelvic exenteration）の適応となる.

\section{3. 術前術後合併症からみた適応}

骨盤内䁍器全摘術の郝後合併症は発生率こそ $50 \%$ 前 後と高(、7)が，手街死亡率は1960年のBrunschwig

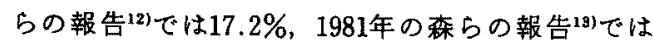
$7.1 \% ， 1986$ 年の骨盤内臓全摘術汇関する全国集計結 果7よれば $4.3 \%$ と年々減少して扸り手術自体の安 全性は高いとい方る。このため, 心血管系, 呼吸器系 に重篤な合併症がなく，患者に本術式の必要性を理解 し，更に術後の状態についても十分炕認識したらえで その実施を受け入れることが可能な知的, 精神的背景 があれば14)，高路であることそれ自体が本術式の禁忌

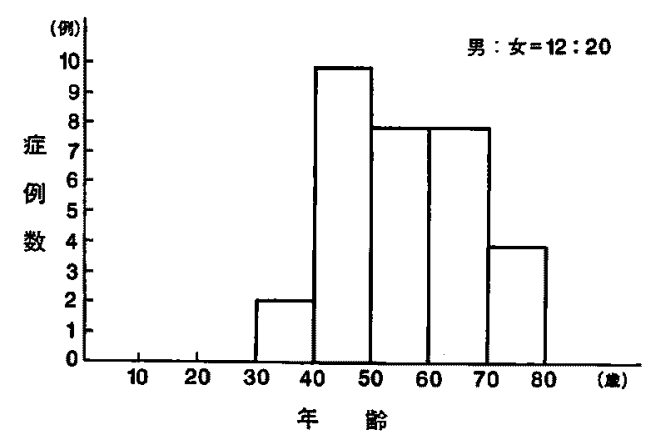

图 1 年踰分布
となることはない、15)，患者の平均年踰は50～60藏代で あり，80歳代に施行した報告むある(1116). 图 1 に当科で の年龄分布を示す。

骨盤内藏器全摘術の適応となる症例では，睡瘍によ る尿管の䦔塞のため術前の腎機能の低下がみられるこ とがしばしばである。この尿管閉塞による腎障害は, 本手術を施行し尿路系の再建を行点ばはとんどの症例 で改善が期待できるため，手術の慗忌の要因となるこ とは少ない，術前検査で行う膀胱鏡検查の際にできる だけ早期に尿管に double J catheterなどの splint catheterを留置することが可能であれば，留機能障害 の進行を予防でき良い全身状態で手術炕望むことがで きる。

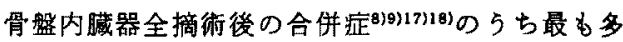
いのは骨盤内感染であるが，無視できない合併症とし て回腸道管採取後の回腸回腸縫合不全がある（表 3 ）. 骨盤内贜器全摘術を行5症例には術前照射が行われた 症例があり放射線性腸资を㧍こした回腸で吻合せざる を得ないこと, 又, 術後小骨盤些の巨大な死腔に小腸 が落ち込むことによる通過障害に起因するものと思わ

\section{表 3 術後合併症}

\begin{tabular}{|c|c|}
\hline 骨船内感染 & 10例 \\
\hline 尿路系感染 & 6例 \\
\hline イレウス & 3例 \\
\hline 尿管綎合不全 & 3例 \\
\hline 回腈回腸吻合部繸合不全 & 1例 \\
\hline
\end{tabular}

(山口大学第 2 外科)

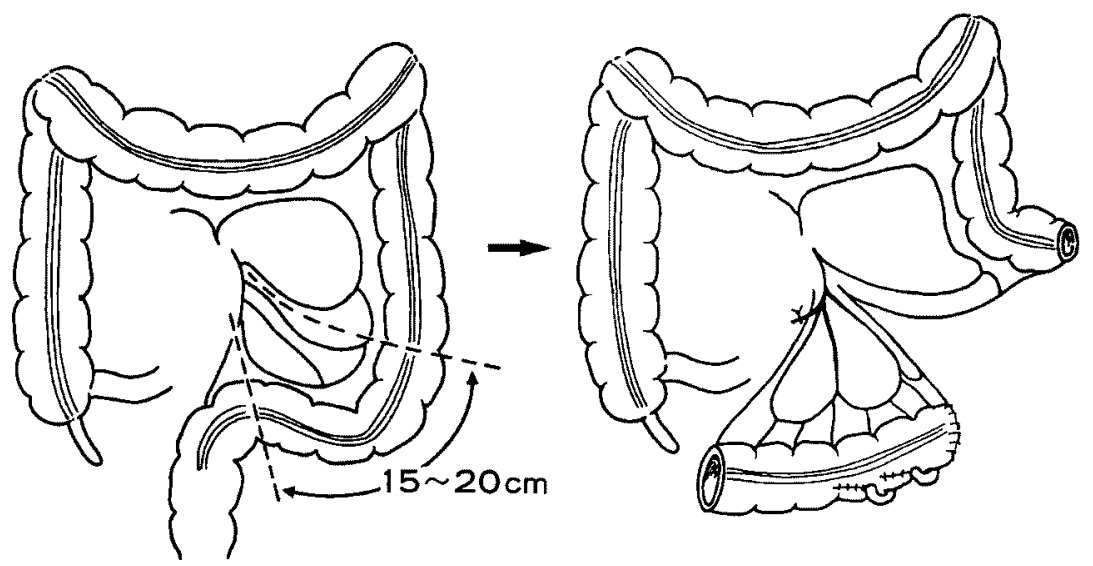

图2 結楊筫管による尿路再建 
れる、このような症例では，放射線障害のない空腸， 横行結腸，下行結腸を導管として用いる方が安全であ るが，われわれは結腸導管を稳極的に用いている(日).わ れわれの方法（図2）では渴管の吻合は不要であり本 法を用いることにより適応が桩大されるすのと思われ る. 又, 尿管の逆流防止機粠の作制が容易であるとい ら利点すある. 教室における骨盤内䁍器全摘術32例の 万ち結腸遵管に上る尿路再建を12例行ったが，早期 の合併症はなく，また長期にわたっても留不全に宿る ことはなく満足すべき結果が得られた，

骨盤内藏器全摘術が肝機能炕与克る影響をみるべく 術後の血清総ビリルビン值の推移をみた(図 3) 201. 術 前值は全例 $1.0 \mathrm{mg} / \mathrm{dl}$ 以下と正常であった，検查値が 完備している28例中19例（68\%）において，1.1mg/dl
以上のビリルビン值の上昇が認められた。

われわれは，この術後高ビリルビン血症の原因が術 中腸管の脱転, または圧排の操作が長時間連続するこ とによる門脈血流量の低下による可能性があると考え 犬を用いた実験を行った。图 4 は小腸を intestinal bag に入れて腹䏸外に脱転，または用手的に上腹部に圧排 する操作を行い上腸間膜静脈血流量をトランシットタ イム血流計で測定した結果を示すか，それそれ 54\%に減少し，解除後もそれそれ77\%，77\%と前值よ り低下が認められ急速に前值に回復することはなかっ な。

この骨盤内䒽器全摘術例における術後ビリルビン値 の上界は第 1 病日にビークを有し，その值が $5 \mathrm{mg} / \mathrm{dl}$ をこえることは稀であった，その後特異な合併症を併

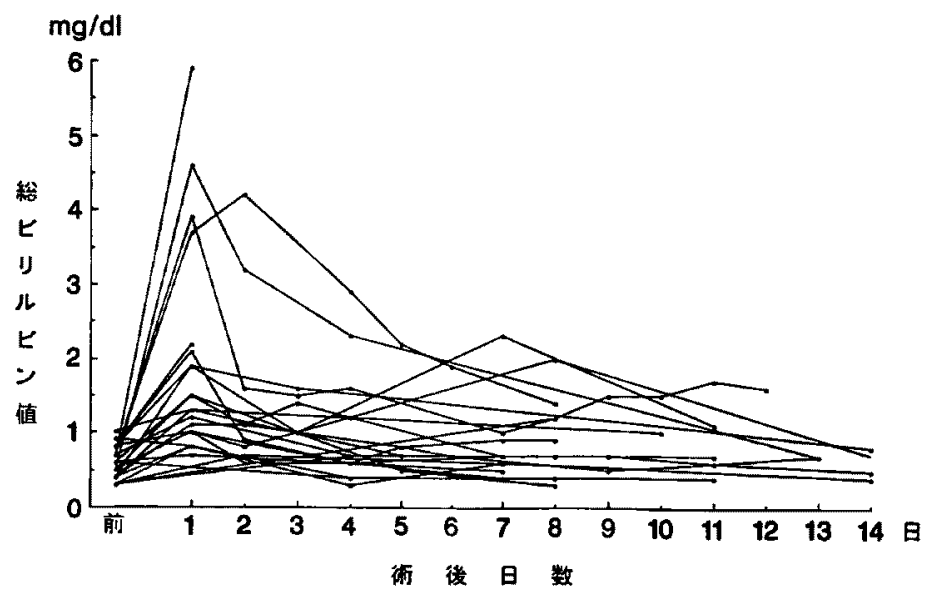

图 3 術後ビリルビン值の推移
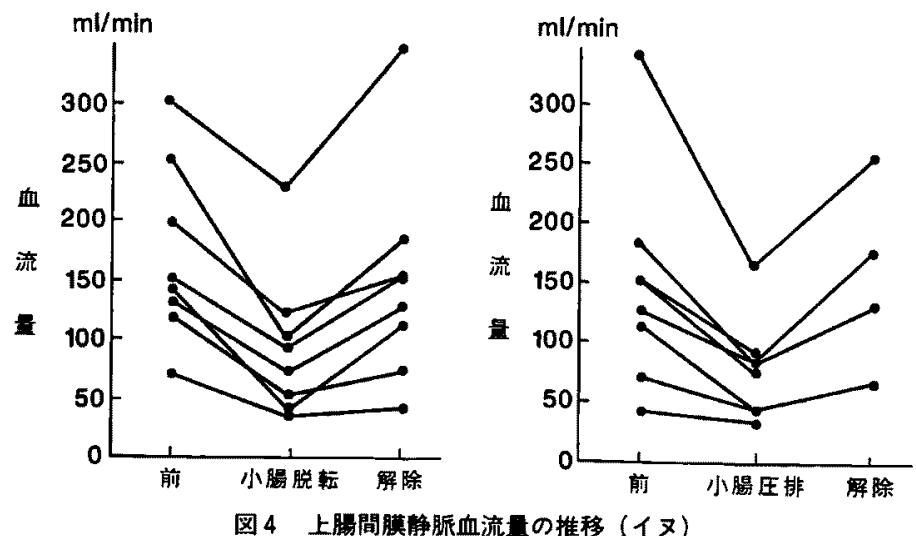

图 4 上得間㬴静脈血流量の推移（イヌ） 
発することがない限り，漸减傾向を迻り，第 7 病日頃 までに約半数は術前値に回復し, 肝不全に陷った症例 は認めなかった。しかし，肝臓との臓器相関性が少な いと思われる骨船内臟器に外科的侵襲が加えられた場 合に怙いても術後肝障害を来す可能性があり，術前肝 障害を有する症例の適応は慎重に考える必要があると 思われた。

\section{4. 適応決定上の問題点と対策}

骨盤内藏器全摘術の基本的な適応条件は，隣接する 他臓器に漫潤した骨船内荿器の悪性腫瘍であるが, 術 後の QOL を考虑すると適応の決定には慎重な態度が 要求され，以下に述へるような場合には問題点および 限界が存在する.（1）術前, 術中に周囲葴器への漫潤 の有無の診断が困難な場合，(2）骨盤壁に浸潤を認め る場合，（3）遠隔臟器転移が存在する場合，（4）旁大 動脈リンパ節転移が存在する場合である．以下これら の問題点ならびにその対策について考察したい.

\section{(1) 周囲臈器への浸潤の診断}

骨盤内撼器全摘術の術前検查を表 4 に示した。この らち局所浸潤状態の診断は本術式が成立するか否かに かかわり，かつ最も困難である. 吉川ら ${ }^{21}$ は，術前およ び術中に $\mathrm{Si}(+), \mathrm{Ai}(+)$ と診断し骨盤内葴器全摘術 を行った原発性直腸癌19例の5ち 6 例が病理組織学的 検査の結果 si (-), ai (ー) であったことを報告し， 壁深達度の不適切な判断として relative contraindication としている. 他施設でも同様の報告22223)があ り診断の困難性を示すむのである。

大腸癌は腸内細菌叢などの関保により癌腫周辺の资 症を起こし易いと言われているが，大腸癌以外の悪性
腫瘍む含めて，癌による 2 次的な炎症が腫掦の周囲に 生じ場合嗹晹の壁深達度の診断は非常に困難とな る、術後の局所再発を防ごうとするあまり, 術前およ び術中に浸潤が疑われる症例では骨盤内䁍器全摘術が 施行され，結果的に over surgery となることがあるの が現状である。しかしながら, 本手衍後は double stoma に代表されるQOL の障害が必発であることを 考えると正診率の上昇が期待される.このための方法 として従来より術中迅速標本による病理組織学的検查 が行われていたが, 最近では衍中擦過細胞診, MRIK よる術前画像診断が行われている.

\section{（a）術中擦過細胞診}

斉藤ら ${ }^{2425)}$ は術中の手術的剝離面の擦過細胞診を併 用して ew の判定を行っているが，本法による判定は 組織学的判定と比較して正診率92\%であり, 術中にお ける最終的な適応の決定に極めて有用な方法であると 述べている。

(b) MRI Kよる画像診断

骨盤内蔵器相互の関係をみるための画像診断法とし ては従来より CT(図 5)が主に用いられている。骨盤 内臟器は, 周囲に脂肪が存在すること, 臟器自体がス ライス面に直交するよらに走行することにより CT に とって有利であるが，腫場自体と各藏器の識別は吸収 値のみからは判定不能で，主に形態により診断するこ とになる. MRI は多因子により信号強度が決定され， 組織間コントラストに勝れ，任意方向の断面像が得ら れる ${ }^{26)}$ といら利点を有し，複雑な立体構造を有する骨 盤内荿器の腫場の浸潤範囲をとらえるには優れている

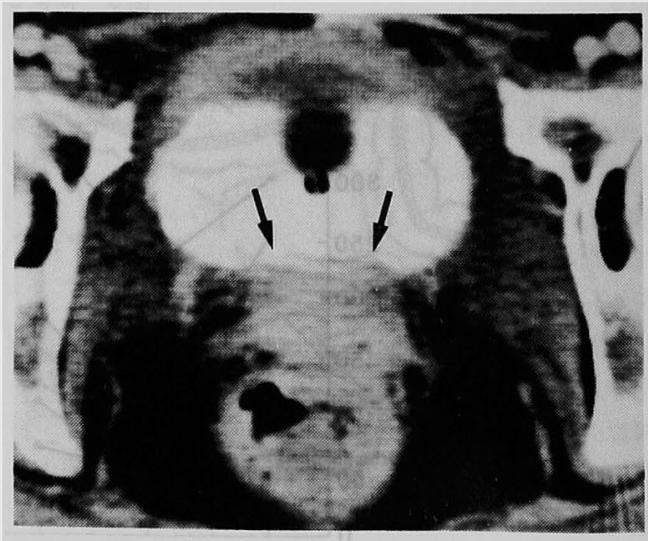

图 5 CT 像：膀脱内腔に突出する目瘤（矢印）を認め 睟睄への浸潤か㠜われる。 


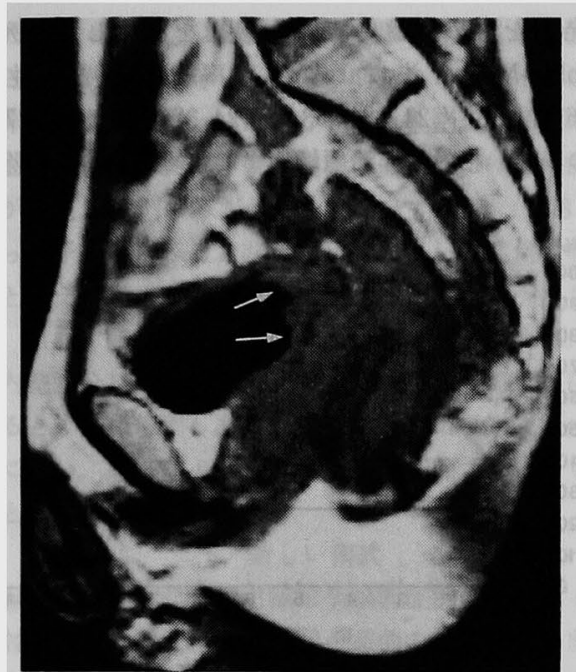

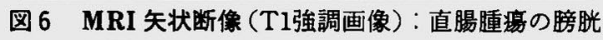
への浸潤（矢印）を認める。

(図 6). 腫腸の漫潤診断ではCTに比し MRI が優れ ているといら報告は多いか，井原 ${ }^{27)}$ は, 直腸癌の壁深達 度を検討し，正診率はCTでは74.6\%, MRIでは 97.1\%であり，MRIはCT による false positive 症例 の除外に有用であったと述べている.

浸潤範囲の診断が困難な症例では，安全域を広く見 込んだ周囲缄器の合併部分切除は手技的に困難である ばかりでなく，例えば広範な膀胱部分切除後の萎縮膀 胼のようにこれのみです術後機能障害を起こしかえっ て QOL が悪くなることがあり，骨盤内䁍器全摘術の 適応とせざるを得ないのが実状である，今後の画像診 断の進歩が期待される.

(2) 骨盤壁漫潤

骨盤内喴器は周囲を仙骨, 尾骨, 腸骨, 恥骨, 坐骨 の骨性骨盤壁に囲まれて存在する。このため原発, 再 発をとわず進行した悪性腫湯は容易に骨盤壁へ進展す る. 森谷ら ${ }^{28)}$ は直腸癌に対する Miles 術後の骨盤壁再 発を, 大坐骨孔周囲で仙骨神経叢に浸潤する型で進展 を示す側方骨盤壁再発と，尾骨，仙骨などへ比較的限 局する型で進展を示す後方骨盤壁再発の 2 型に分類 し，多くの側方骨盤壁再発症例は側方リンパ節転移の 不完全郭清の結果であろらと述べているが，同様の進 展型式は，大腸のみならず膀胼，子宮，胵の悪性腫瘍 においても原発，再発をとわず成立する．以下骨盤内 缄器全摘術が必要な症例において骨盤壁への浸潤も
伴っている場合の適応について考察する.

上に述へたように，進展方向により側方，後方に分 類され，手術適応を考える場合にはこの 2 つを分けて 考える必要がある. 即ち後方の骨盤壁への進展例は, 尾骨，仙骨を合併切除することにより根治性が得られ るが2930)，側方への進展例では合併切除不可能な股関 節部，坐骨神経が存在することから通常の方法では根 治的切除が不可能である。このような症例では根治性 を追求すれば骨盤内蔵器全摘術に加えて下肢を含めた 骨盤壁の半切を行うことになるが，術後のQOLが極 めて悪いことを考えると，この施行にはひかえめにな らざるを得ない。

仙骨の切除可能な範囲は, 骨盤の安定性と下肢の運 動性の両面上り制約がある. 骨盤の安定性からは仙腸 関節の部が温存されるように斜めに切離ラインを設定 すれば第 1 仙椎の切除まで可能である ${ }^{31)}$. また, 下肢の 運動珄はS1の仙骨神経が温存されれば歩行障害は生 じないといわれており 28)32)第 2 仙椎以下の切離には何 ら問題はない. 前谷ら $\left.{ }^{33}\right)$ は, 恥骨, 坐骨の部分切除も 行っており側方への進展例む同部までであれば合併切 除可能である.

以上のよ5に骨盤壁へ進展した症例の骨盤内葴器全 摘術の商応は, 浸潤が第 2 仙椎以下の仙骨, 坐骨, 恥 骨のみに及ぶものであり，側方の坐骨神経，股関節ま で及ぶものでは限界がある。

このよらな症例に対する治療法としては術中照射の 併用がある，術中照射は病巣に限局した高線量の照射 が可能で 1 回照射の生物学的効果が体外分割照射の 2 ～2.5倍といわれ ${ }^{34)}$, 放射線感受性の低い腺癌でも効果 が期待できる，側方の限局した切除不能な部位に対し 術中照射を併用することによりこのよらな症例での骨 盤内䁍器全摘術の適応の払大化が計れる可能性があ る.

\section{（3）遠隔朖器転移}

Brunschwig や Bricker らが骨盤内臓器全摘術をは じめて以来長い間, 肝, 肺などへの血行性遠隔缄器転 移のある症例では本術式は禁忌とされていた，近年の 画像診断の発展により術前に転移状況がほぼ正確に把 握できるよらになったこと，また，手術手技が向上し たことにより現在では骨盤部および遠隔葴器の腫瘍が 共に根治的切除可能な症例では遠隔藏器転移は骨盤内 臓器全摘術の適応の妨げとはならないといらことで consensus が得られつつある。骨盤内藏器の解剖学的 特性によりその還流静脈血は，門脈または，直接下大 
静脈にそそぎ，肝，肺は最初の涌過臓器となりこれら に転移があってもまだ全身化する転移には至っていな い状態である可能性がある35)ことも積極的切除の理論 的根拠となっている. しかしながら，外科的に処理し らる転移の個数には打のずと制限があり，適応となる 症例の長期生存を前提とした場合，大腸癌では，肝転 移は 4 個以下 ${ }^{36)}$ ，肺転移は雨側転移を含めて 2 個以 下年などとされており，これ以上の場合は症例每に娭 討する必要がある。骨盤内藏器全摘術は長時間を要す る手術であり，転移巣切除が過度な侵襲となる場合は 転移巣を二期的に切除すべきである，特に肺転移は手 術創る別であり二期的切険になることが多い.

根治的切除不能な多発性の遠隔葴器転移がある場合 は適応の限界といわざるを得ない。

（4）芳大動脈リンパ節転移

骨盤内臓器からみれば遠隔(大腸癌でいえば第 4 群) リンバ節である旁大動脈リンバ節に転移がある場合に は骨盤内藏器全摘術が適応となるか否かは意見の一致 をみない，われわれは，術前の画像診断により同転移 リンパ節が完全郭清可能な腎静脈以下にとどまる症例 においては相対的非治瘦切除が行えることから骨盤内 䁍器全摘術を積極的に行ら方針である。

5.予啳からみた適応と姑息的手術の意義

第24回大晹癌研究会骨盤内臟全摘に関寸る全国集計 結果》によと累積 5 年生存率は原発直腸癌で $42.0 \%$, 原発 S 状結腸癌で $47.3 \%$ となっているが, 治 瘾切除か非治痖切除かでみるとそれぞれ $50.6 \%, 4.0 \%$

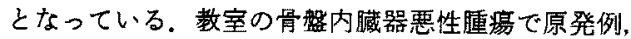

再発例を含め骨盤内贜器全摘術を施行した28例の Kaplan-Meiyer 法による生存率をみると 1 生率 $48.6 \% ， 2$ 生率 $24.3 \% ， 3$ 生率24.3\%である(図 7).

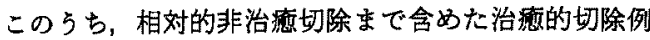

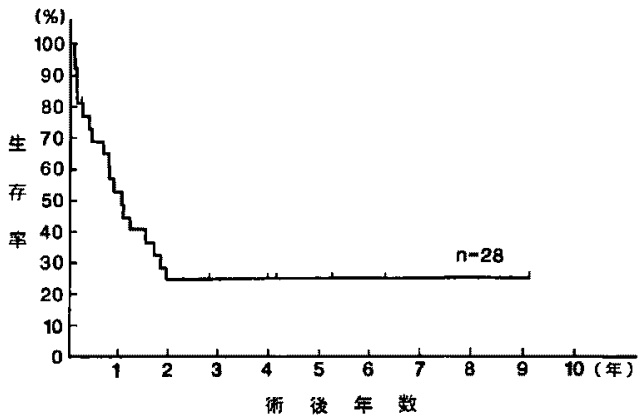

図 7 術後生存率 (全症例)

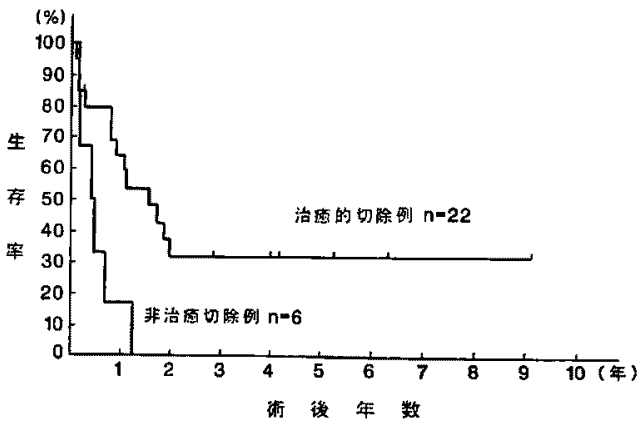

图 8 術後生存率
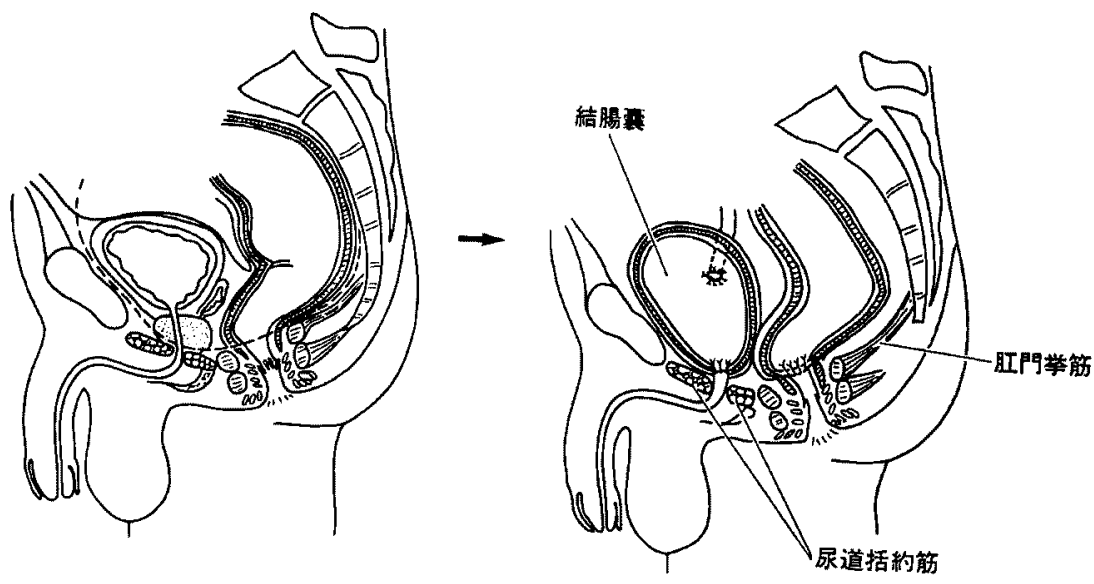

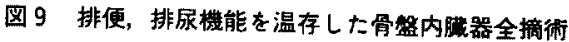


については，1生率53.1\%，2生率31.9\%，5生率 31.9\%であるのに対し，腫場の明らかな取り残しがあ る非治撚切除に終わったもの6 例は全例15力月以内に 死亡しており，長期予後を期待するためには治癁的切 除が行支る症例のみが適応となるとい点る（国 8）。 従って予後加らみると非治源切除に終わる庭例は非適 応といえるが，このような症例でも control 不能な疼 痛，出血，瘦孔形成などの局所症状が強い場合は，骨 盤内眼器全摘術を行った方がむしろ良いQOL が得ら れるとする報告 ${ }^{38}$ むる。特に最近の集学的治療の進 步に伴い，症例に上っては非治癁的切除であって子適 応として良いものもあろう。

\section{6. 新しい術式}

以前に行われた骨盤内葴器全摘術症例の摘出標本を 㭲討すると，悪性腯煬の浸潤が頭側のみで尾側の前立 腺，䢸門などは温存できる症例が含主れていることに 気付く．これは特にS 状結腸癌の浸澗例に多い，近年 直腸癌に対しては超低位切除儿上る肛門括約筋温存術 が頻繁に行われる上らになり，一方泌㲾器科項域では 各㣫の腸管で作製した reservoir を直接尿道に伆合す る neobladder の報告がなされている。これらの2つ の方法を合わせれば骨盤内臟器全摘街後に排便機能， 排尿機能を温存することが可能であることが推測され る(图 9). Skinner 5991 は1990年 pelvic sarcoma $に$ 対して骨盤内䁍器全摘術を行い，EEAを用いた結腸の J pouch と肛門との吻合および Kock ileal reservoir を用いた尿道回腸吻合を行った 2 例を発表している。 畽演の浸潤が尿道, 肛門管に及んでいない症例はこの 排便，排尿機能温存術式の適応となり，本術式は術後 QOL が良いことより骨盤内臟器全摘術の適応の抁大 に寄与するすのと思われる。

\section{7.まとめ}

骨盤内眮器全摘䚘の適応は以下にまとめる.

（1）心血管系，呼吸器系に重第な合併症がなければ 年龄に制限はない。

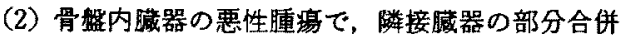
切除のみでは根治性の得られない隣接臟器浸湎例, 即 ち膀脱三角部，前立腺，直腸などに広䇶围に浸潤する 症例である。これらには原発性，再発性のものが含ま 九る。

（3）骨盤壁への進展例では，完全切除が容易な第 2 仙椎以下の仙骨のみ，または，恥骨，坐骨のみに浸潤 する症例.

（4）肝，肺などの遠隔転移を有するすのでは，これ
らが一期的または二期的㶤切除可能な覜囲に存在する 症例.

（5）逼隔転移などのために非治䈍切除に終わらざる を得ないが, control 不可能な疼痛, 出血, 瘦孔形成な ぞの局所症状が強い症例の中の一部。

これらのうち肉眼的治痹切除が可能な症例は長期予 啳も期待でき最も良い適応といえる。

側方骨盤壁への高度進展例，多発性に遠隔藏器転移 を来している症例，広籍なリンバ節転移例なとの一部 に対しても，術中照射の併用，集学的治療などにより 将来的には適応拡大の可能性がある。 また，排便排层 機能を温存した骨盤内贜器全摘術の施行が可能であれ ば術後のQOL が保たれることから，更に積極的な適 応の搪大が期待されるものと思われる。

\section{文献}

1) Brunschwig A: Complete excision of pelvic viscera for advanced carcinoma. Cancer $1: 177$ $-183,1948$

2) Appleby LH: Proctocystectomy ; the management of colostomy with ureteral trans-plants. Am J Surg 79: 57-60, 1950

3) Bricker EM, Modline $\mathrm{J}$ : The role of pelvic evisceration in surgery. Surgery $30: 76-94$, 1951

4) Bricker EM: Substitution for the urinary bladder by the use of isolated ileal segments. Surg Clinic N Amer 36 : 1117-1130, 1956

5）高安久婎, 枯崎 勉, 西浦常婎他：直腸癌の膀胱侵 鼠例に施行せる骨盤内喴器全剔術に就いて，日必 尿会誌 $42: 183-189,1951$

6）大村裕子，穴沢貞男：ダブルストーつの管理，臨外 $45: 429-434,1990$

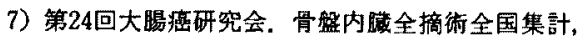
1986

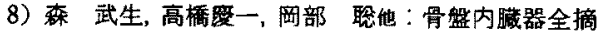
術の遥応と問題点，臨外 $45: 985-990,1990$

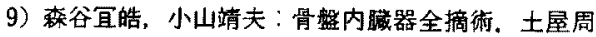
二, The latest therapy 4, 大腸癌の治療，医学教 充出版社，東京，1986，pl69-182

10) Bricker EM, Butcher HR, Lawler WH : Surgical treatment of advanced and recurrent cancer of the pelvic viscera: An evaluation of ten years experience. Ann Surg 152: 388-402, 1960

11) Gordon HH, Lemuel H, Nicholas JP: Morbidity and mortality after pelvic exenteration for 
colorectal adenocarcinoma. Ann Surg 215: 63 $-67,1992$

12) Brunschwig A, Daniel W: Pelvic exenteration operations: With summary of sixty-six cases surviving more than five years. Ann Surg 151 : $571-576,1960$

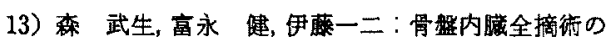

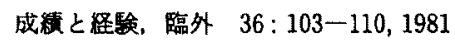

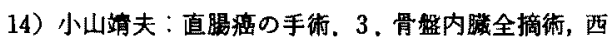
满正，大腸癌の臨床，一るす出版，東京，1984，p439 $-448$

15) Burber HRK : Relative prognostic significance of preoperative and operative findings in pelvic exteration. Surg Clin North Am $49: 431-447,1969$

16）磯本浩晴, 小息敏生, 土田 勇他：骨盤全摘術の適 心と限界，日消外会誌 $17: 256,1984$

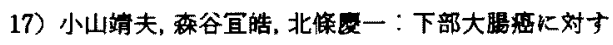
万骨然内睛全摘術，外科治療 $52: 181-188,1985$

18）高木 弘：手術一骨盤内贜器全摘術一，外科治虔 $65: 49-56,1991$

19）根木逸郎, 秀浦信太郎, 松村照男他：骨盤内膜器全 摘術の経験と合併后に対する対策，手術 37 : 1299-1304, 1983

20）内山哲史, 水田英司, 広瀬嘉明他：骨盤内減器全摘 㭪後の高ビリルビン血症について一㯺床的ならび に実験的検討，日外会誌 $90: 354,1989$

21) 吉川宣媈：骨盤内䁍器全摘術一とくに直渴海に対 する本術式の relative contraindication kついて 一, 日消外会誌 $17: 2044-2050,1984$

22）森武生，林和雄，富永 建他：骨盤内滕器全剔 例の検討，日本大腸肛門病会誌 $40: 94,1987$

23）松田秦次，八田甼樹，西山真一他：骨盤内䑏全摘術

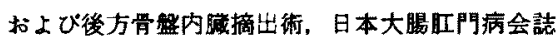
$40: 95,1987$

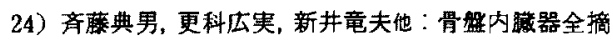
術の適応決定方針とその治㞠予後，日本大腸肛門 病会誌 $40: 510,1987$

25）齐滕典男, 更科広実, 布村正夫他：大腸癌に和ける 骨盤内䑏器全摘政の適応と限界, 日臨外医会誌
$52: 105,1991$

26）板井悠二：進行下部直渴癌，この症例で術前さら に行う検查, 術前評価について, 外科 49：972 -977, 1987

27）井原真都：Magnetic resonance imaging Kよる 直腸癌翮断の検討一術前進行度および術後局所再 発について一，日消外会誌 $23: 875-883,1990$

28）森谷冝皓，小山靖夫，北條度一地：進行直腸癌, 拧 よび局所再発直腸涭に対する仙骨合併骨盤内䑏器 全摘術一適応，手術手技と6 症例の報告一，日本大 腸肛門病会福 $38: 7-15,1985$

29）高木 弘, 渡辺 正, 山内晶司他：直晹癌に対する

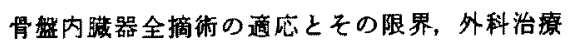
$54: 121-126,1986$

30) Wanebo HJ, Marcore RV: Abdominal sacral resection of locally recurrent rectal cancer. Ann Surg 194: 458-471, 1981

31）奥山利明，栗野友太，唐司則之他：骨盤内絾全摘術 の通応と限界，日臨外医会誌 $52: 106,1991$

32) Stener B, Gunterberg B : High amputation of the sacrum for extirpation of tumors. Principles and technique. Spine 3:351-366, 1978

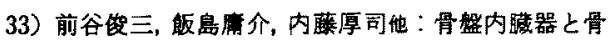
盤壁の拡大合併切除, 手術 38:637-644, 1984

34）野恭一, 癿岡信悟, 太田代安律：直腸癌一彭断・ 治癔の進步，合併癔法一術中照射とその問題点一, 外科治療 $65: 57-63,1991$

35）末桝恵一，米山武忘，成毛韶夫他：がん転移の基礎 と臨床, 癌と化療 $14: 561-566,1987$

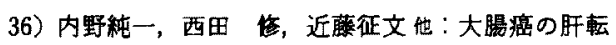
棃，手術 $43: 1707-1714,1989$

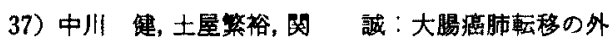
科治㩧，手術 $43: 1699-1705,1989$

38) Deckers PJ, Olsson C, Williams LA, et al: Pelvic exenteration as palliation of malignant disease. Am J Surg 131: 509-515, 1976

39) Skinner DG, Sherrod A : Total pelvic exentration with simultaneous bowel and urinary reconstruction. J Urol $144: 1433-1439,1990$ 